Care: Jurnal Ilmiah Ilmu Kesehatan Vol .6, No.3,2018,hal 267-276

Tersedia online di https://jurnal.unitri.ac.id/index.php/care

ISSN 2527-8487 (online)

ISSN 2089-4503 (cetak)

\title{
Pemberian Sirup Zink Berpengaruh Terhadap Perubahan Berat Badan Pada Balita Kekurangan Energi Protein (KEP) Sedang
}

\author{
Rifzul Maulina, Tut Rayani Aksohini Wijayanti \\ Poltekkes RS dr Soepraoen \\ e-mail: rifzulmaulina3@gmail.com; tutrayani@gmail.com
}

\begin{abstract}
Lack of nutrients will cause the body's nutrient stores to be used to needs so it can cause weight loss and result in stunted growth and development. The incidence of malnutrition should be overcome more quickly by giving zinc syrup to toddlers with poor nutrition. This study aims to determine the effect of giving zinc syrup on changes in body weight in infants lacking moderate and severe protein energy. The design of this study use preexperiment with pre and post test design. The population used was all children under five who experienced moderate and severe protein energy deficiency in the Jabung Community Health Center work area. The sample in this study were 20 toddlers who experienced severe protein energy deficiency with a sampling technique which was purposive sampling. Samples were given zinc syrup for 2 months at a dose of $1.25 \mathrm{mghari}$ then an evaluation was conducted to measure the weight of a toddler. The average toddler weight gain for 2 months after giving of zinc syrup is $0.58 \mathrm{~kg}$. This study using observation sheets and data were analyzed using Wilcoxon. That there is an effect of zinc symp administration on weight changes in children underweight with moderate and severe protein energy (pvalue 0,034). This shows that zinc syrup can cause weight changes, namely weight gain. For future researchers to provide zinc syrup with a longer time is at least 3 months so that the results obtained are more optimal.
\end{abstract}

Keywords: childen; weight change; zinc

\begin{abstract}
ABSTRAK
Kekurangan zat gizi balita menyebabkan penurunan berat badan dan berakibat terhambatnya pertumbuhan dan perkembangan. Kejadian gizi kurang bisa diatasi dengan lebih cepat dengan pemberian sirup zink pada balita gizi kurang dan buruk. Penelitian ini bertujuan untuk mengetahui pengaruh pemberian sirup zink terhadap perubahan berat badan pada balita kekurangan energi protein sedang dan berat. Desain penelitian ini menggunakan pre eksperimen dengan pendekatan pre and post test design. Populasi adalah semua balita yang mengalami kekurangan energi protein sedang di wilayah kerja puskesmas Jabung. Sampel sebanyak 20 balita yang mengalami kekurangan energi protein (KEP) sedang dengan teknik sampling yaitu purposive sampling. Sampel diberikan sirup zink selama 2 bulan dengan dosis 1,25mghari kemudian dilakukan evaluasi untuk mengukur berat badan balita. Pengumpulan data dalam penelitian ini menggunakan lembar observasi yaitu berat badan balita yang diukur sebelum dan sesudah pemberian sirup zink. Rata-rata kenaikan berat badan balita selama
\end{abstract}

Cara mengutip: Maulina, R., Wijayanti,TRA.(2018). Pemberian Sirup Zink Berpengaruh Terhadap Perubahan Berat Badan Pada Balita Kekurangan Energi Protein (KEP) Sedang Care: Jurnal Ilmiah Ilmu Kesehatan, 6(3), 267-276.

Retrieved from https://jurnal.unitri.ac.id/index.php/care/article/view/1001 
2 bulan setelah pemberian sirup zink $0,58 \mathrm{~kg}$ dan dianalisa menggunakan Wilcoxon.Hasil menunjukkan ada pengaruh pemberian sirup zink terhadap perubahan berat badan pada balita kekurangan energi protein sedang dan berat ( $p$ value 0,034$)$. Sirup zink dapat menyebabkan perubahan berat badan yaitu peningkatan berat badan. Saran untuk peneliti selanjutnya agar memberikan sirup zink ini dengan waktu lebih lama yaitu minimal 3 bulan sehingga hasil yang didapat lebih optimal.

Kata kunci :balita; perubahan berat badan; zink

\section{PENDAHULUAN}

Beberapa faktor yang berpengaruh terhadap asupan makanan antara lain kebiasaan makanan, rasa suka dan tidak suka terhadap makanan tertentu akan terbawa sampai dewasa dan seringkali sulit diperbaiki, termasuk juga lingkungan keluarga, media massa, teman sebaya dan penyakit.Tumbuh kembang anak dapat terganggu akibat dari masalah yang dihadapi salah satunya sulit makan Sedikitnya makanan yang masuk ke dalam perut anak dapat menjadi indikasi bahwa anak mempunyai peluang besar untuk menderita kurang gizi.Kekurangan zat gizi akan menyebabkan cadangan makanan yang ada di dalam tubuh diambil untuk pemenuhan kebutuhan metabolisme tubuh. Penurunan Jaringan akan terjadi apabila simpanan zat gizi digunakan dalam jangka waktu yang lama.Pada saat terjadi kemerosotan jaringan inilah orang sudah dapat dikatakan malnutrisi dan hal ini biasanya ditandai dengan adanya penurunan berat badan dan perkembangan terhambat.
Adanya pemberian sirup zink pada balita mengakibatkan perubahan berat badan. Hal ini karena zink sebagai mineral mikro yang terdapat dalam jumlah sangat kecil di dalam tubuh memegang peranan penting dalam banyak fungsi tubuh. Almatsier, S (2003) menyatakan peran zink dalam aspek metabolism, seperti sintesis dan degradasi karbohidrat, protein, lipida dan asam nukleat. Sebagai bagian dari enzim peptidase karboksil yang terdapat di dalam cairan pancreas, zink berperan saat pencernaan protein. Berdasarkan penelitian yang dilakukan oleh Dwi Hastuti (2006) di Puskesmas Sidotopo, Surabaya didapatkan hasil kenaikan berat badan balita pada 20 balita dari 29 balita dengan rerata kenaikan $0,98 \mathrm{~kg}$ setelah diberikan sirup zink selama 3 bulan dengan dosis 1 sendok teh sehari sekali.

Dari hasil Pemantauan Status Gizi Balita (PSG) yang dilaksanakan setiap tahun di Kabupaten Malang menunjukkan persentase gizi buruk dan gizi kurang 
2005-2007 mengalami peningkatan dan tahun 2007- 2009 mengalami penurunan meskipun penurunannya relatif kecil sedangkan tahun 2008-2012 prevalensi kasus gizi kurang mengalami penurunan dari 13,01\% tahun 2007 menjadi 6,14\% tahun 2012 dan prevalensi gizi buruk dari 1,01\% tahun 2008 menjadi 3,40\% tahun 2010, sedangkan tahun 2012 prevalensi gizi buruk turun sebesar $0.84 \%$. Hasil Riset Kesehatan Dasar (Riskesdas) tahun 2007 di Jawa Timur prevalensi balita gizi buruk sebesar 4,8\% dan balita gizi kurang sebesar 12,6\% dan di Kabupaten Malang prevalensi balita gizi buruk sebesar 3,1\% dan balita gizi kurang sebesar 9,4\%. Hasil PSG tahun 2011 bila dibandingkan dengan hasil Riskesdas tahun 2007, maka prevalensi gizi buruk dan prevalensi gizi kurang hasil PSG lebih rendah daripada hasil Riskesdas.Berbeda pula dengan hasil Putri,RM., Maemunah, N., Rahayu,W (2016) yang melakukan pemantauan tinggi dan berat badan, dan didapatkan sebagian besar anak (40 anak) di TK Al Madaniyah Landung Sari Malang mempunyai berat bdan dan tinggi badan yang sesuai. Hasil ini menunjukkan bahwa status gizi anak dalam keadaan baik.

\section{METODE PENELITIAN}

Desain Penelitian dalam penelitian ini adalah pre eksperimen dengan pendekatanpre and post test design. Waktu pemberian sirup zink adalah selama 2 bulan. Pemberian sirup zink dengan dosis 1,25 mg (setara 1 sendok teh) diberikan sehari sekali.

Populasi dalam penelitian ini adalah balita dengan KEP sedang yang diberi sirup zink sebanyak 20 orang. Sampel yakni semua balita mi KEP sedang dan berat yang memenuhi kriteria inklusi dan eksklusi. Dalam penelitian ini kriteria inklusinya adalah balita dengan KEP sedang, balita yang tidak mendapatkan PMT serta balita yang tidak sedang menderita penyakit pencernaan.

Teknik yang digunakan dalam penelitian ini adalah purposive population sampling dengan cara mengambil semua populasi sebagai sampel. Teknik analisa data digunakan untuk mengetahui ada tidaknya pengaruh pemberian sirup zink terhadap perubahan berat badan pada balita dengan KEP sedang dan berat.

Instrumen penelitian yang digunakan dalam penelitian ini adalah lembar observasi yaitu berat badan balita yang diukur sesudah dan sebelum perlakuan. Alat ukur yang dipakai dalam pengukuran berat badan ini adalah timbangan dacin.Pada penelitian ini menggunakan uji statistik Wilcoxon. Etika Penelitian ini 
meliputi informed consent (lembar persetujuan) yang diberikan kepada ibu yang memiliki balita, anonymitydengan hanya memberikan initial pada responden, serta bersifat rahasia

\section{HASIL PENELITIAN}

Penelitian ini dilakukan di Puskesmas Jabung yang terletak di Kabupaten Malang. Puskesmas ini membawahi 8 desa. Penelitian ini dilakukan di desa Sukopuro dan Kemiri Dalam penelitian ini, hasil penelitian dibagi menjadi dua data yaitu data umum dan data khusus. Data umum yang disajikan meliputi umur balita, jenis kelamin, pola konsumsi balita dan tingkat pendidikan ibu sedangkan data khusus meliputi berat badan balita sebelum dan sesudah diberi sirup zink selama 2 bulan.

Tabel 1. Distribusi Frekuensi Umur Balita di Puskesmas Jabung Periode April-Juni 2018

\begin{tabular}{lcc}
\hline Umur Balita & Jumlah & $\%$ \\
\hline 6-12 bulan & 2 & 10 \\
12-24 bulan & 6 & 30 \\
$24-60$ bulan & 12 & 60 \\
\hline Total & 20 & 100 \\
\hline
\end{tabular}

Tabel 1 menunjukkan sebagian besar (60\%) umur balita antara 24-60 bulan.
Karakteristik responden berdasarkan jenis kelamin diketahui sebanyak 12 orang $(60 \%)$ berjenis kelamin wanita dan 8 orang (40\%) laki-laki

Tabel 2. Distribusi Frekuensi Pola Konsumsi Balita di Puskesmas Jabung Periode April-Juni 2018

\begin{tabular}{lcc}
\hline Pola konsumsi & Jumlah & $\%$ \\
\hline$<3$ kali & 6 & 30 \\
$\geq 3$ kali & 14 & 70 \\
\hline Total & 20 & 100 \\
\hline
\end{tabular}

Tabel 2 menunjukkan hasil bahwa sebagian besar $(70 \%)$ pola konsumsi balita yaitu konsumsi makanan $\geq 3$ kali sehari

Tabel 3. Distribusi Frekuensi Pendidikan Ibu Responden di Puskesmas Jabung Periode April-Juni 2018

\begin{tabular}{lcc}
\hline Pendidikan Ibu & Jumlah & $\%$ \\
\hline SD & 5 & 25 \\
SMP & 9 & 45 \\
SMA & 6 & 30 \\
PT & 0 & 0 \\
\hline Total & 20 & 100 \\
\hline
\end{tabular}

Tabel 3 menunjukkan hasil bahwa hampir setengahnya sebanyak 45\% (9 orang) tingkat pendidikan ibu adalah SMP.

Berdasarkan Gambar 1 menunujukkan bahwa terdapat perubahan berat badan pada balita dengan KEP sedang dan berat setelah diberi sirup zink selama 2 bulan. 


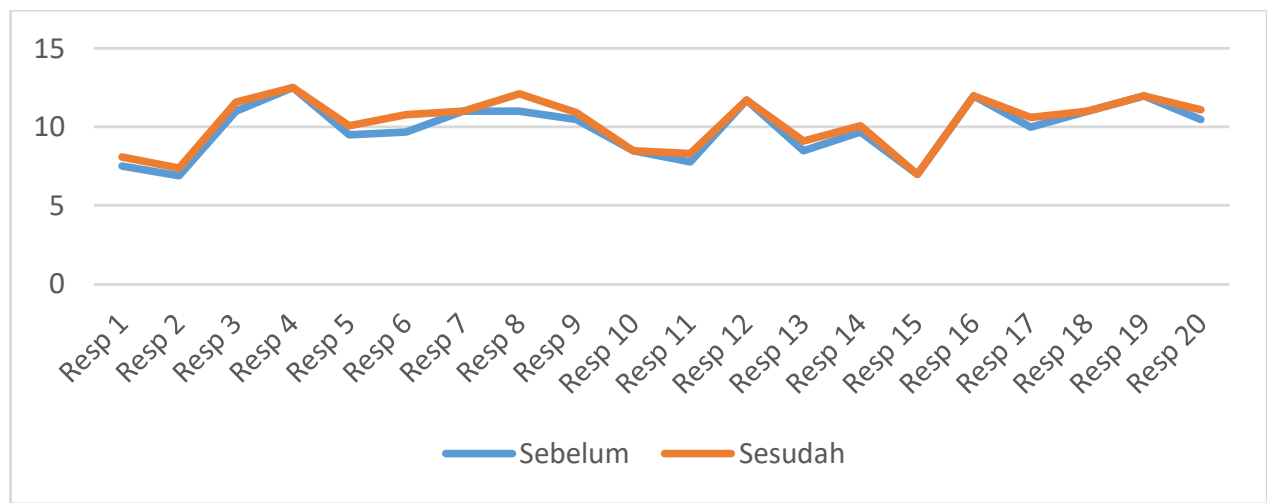

Gambar 1 Berat badan balita sebelum dan sesudah perlakuan (pemberian sirup zink)

Tabel 4. Hasil Observasi Perubahan Berat Badan Setelah diberi Pemberian Sirup Zink Selama 2 bulan

\begin{tabular}{lcc}
\hline $\begin{array}{l}\text { Perubahan } \\
\text { Berta Badan }\end{array}$ & Jumlah & $\%$ \\
\hline Naik & 13 & 65 \\
\hline Tetap & 7 & 35 \\
\hline Turun & 0 & 0 \\
\hline Total & 20 & 100 \\
\hline
\end{tabular}

Berdasarkan Tabel 4 terlihat bahwa setelah pemberian sirup zink selama 2 bulan pada balita dengan KEP sedang dan berat sebagian besar mengalami kenaikan berat badan sebanyak 13 orang (65\%).

Uji statistik menggunakan Wilcoxon disimpulkan ada pengaruh pemberian sirup zink terhadap perubahan berat badan balita pada balita dengan KEP sedang dan berat. $($ pvalue $=0,034)$.

\section{PEMBAHASAN}

Balita yang terpilih sebagai sampel dalam penelitian ini adalah Balita yang berusia antara $6-60$ bulan dengan status KEP sedang di wilayah kerja Puskesmas Jabung
Kabupaten Malang. Pada penelitian ini sampel berjumlah 20 orang.

Umur Balita pada saat penelitian pada sebagian besar $(60 \%)$ berusia antara 24-60 bulan, dan pada sebagian besar (60\%) berjenis kelamin perempuan.. Pada usia Balita merupakan masa yang sangat rentan terhadap penyakit gizi. Menurut Suhardjo (1997) menyebutkan bahwa pada kelompok usia balita dan prasekolah kebutuhan kalori (per kg/BB) tidak setinggi pada masa bayi dan nafsu makannya juga menurun. Disamping itu anak pada masa balita selektif terhadap makanan, tidak tergantung dengan makanan, pertumbuhannya pelan dan tidak tetap sehingga berat badannya cenderung turun, anak sudah mempunyai perhatian lain, dan perkembangan kondisi emosional serta sosialisasi.

Pola konsumsi adalah cara yang ditempuh seseorang atau sekelompok 
orang yang memilih dan mengkonsumsinya sebagai reaksi terhadap pengaruh fisiologis, psikologis, budaya, dan sosial (Suhardjo, 2008). Pola konsumsi makanan Balita (frekuensi makan) dalam sehari pada sebagian besar (70\%) frekuensi makannya $\geq 3$ kali dalam sehari, walaupun ada beberapa balita (30\%) frekuensi makannya $<3$ kali dalam sehari, hal ini disebabkan setiap pagi balita hanya minum susu.

Ibu balita hampir setengahnya (45\%) berpendidikan SMP. Hal ini juga dikemukakan oleh Supariasa (2009) bahwa ibu rumah tangga dengan tingkat pendidikan yang rendah akan menyebabkan pengetahuan yang terbatas sehingga mempengaruhi kualitas perencanaan pola makan keluarga yang lebih lanjut dan akan berpengaruh juga terhadap keadaan status gizi dan anggota keluarga.

\section{Berat Badan Sebelum Perlakuan.}

Pada penelitian ini, status gizi Balita berdasarkan indeks BB/U pada sebelum diberi perlakuan seluruhnya (100\%) adalah rendah. Menurut Suhardjo (2008) bahwa status gizi sebagai refleksi kecukupan zat gizi, merupakan salah satu parameter penting dalam menilai tumbuh kembang anak dan kesehatan pada umumnya. Kecukupan dari zat gizi terutama energi dihitung menurut kebutuhan atas umur, jenis kelamin, aktifitas maupun kondisi dari individu. Anak yang sehat akan mengalami pertumbuhan dan perkembangan yang normal dan wajar, yaitu sesuai standar pertumbuhan fisik anak pada umumnya dan memiliki kemampuan sesuai standar kemampuan anak seusianya (Supariasa, 2009).

Berat badan merupakan ukuran antropometrik yang penting digunakan untuk mengukur status gizi. Berat badan merupakan hasil peningkatan atau penurunan semua jaringan yang ada pada tubuh antara lain tulang, otot, lemak, cairan tubuh, dan lain-lain. Berat badan dipakai sebagai indikator yang terbaik untuk mengetahui keadaan gizi dan tumbuh kembang anak dan sangat sensitif terhadap perubahan sedikit saja (Supariasa, 2009).

\section{Berat badan sesudah perlakuan}

Berdasarkan hasil penelitian setelah pemberian sirup zink selama 2 bulan pada balita dengan KEP sedang sebagian besar mengalami kenaikan berat badan sebanyak 13 orang (65\%). Berat badan yang meningkat disebabkan suplemen zinc 
sulfat pada tubuh Balita sudah mulai bereaksi, sehingga konsentrasi seng didalam tubuh meningkat. Hal ini dapat ditunjukkan dengan adanya peningkatan ketajaman indra rasa yang mengakibatkan nafsu makan meningkat, dan menstabilkan struktur pembelahan sel. Dengan meningkatnya nafsu makan Balita, maka tingkat konsumsi zat gizi dalam tubuh juga meningkat, sehingga berat badan Balita akan tumbuh dan berkembang secara optimal.

Setiap manusia yang hidup mengalami proses tumbuh kembang, tumbuh berarti berkaitan dengan perubahan ukuran, sedangkan kembang berhubungan dengan aspek deferensiasi bentuk atau fungsi termasuk perubahan emosi dan sosial. Tumbuh kembang merupakan proses continue sejak dari konsepsi sampai maturasi atau dewasa yang dipengaruhi oleh faktor bawaan dan lingkungan (Supariasa, 2009).

Seng ( $\mathrm{Zn}$ ) merupakan zat gizi yang esensial dan telah mendapat perhatian yang cukup besar akhir-akhir ini. Seng berperan untuk bekerjanya lebih dari 70 macam enzim karena peranannya dalam sintesa AND, ARN (keduanya unsur utama genetika), dan protein. Maka defisiensi seng dapat menghambat pembelahan sel, pertumbuhan dan pemulihan). Ada kemungkinan seng berinteraksi dengan defisiensi vitamin A dalam proses terjadinya buta senja (Almatsier, 2003).

Berdasarkan hal tersebut diatas, maka kebutuhan akan makanan sumber seng serta makanan yang dapat meningkatkan absorpsi seng pada Balita harus diperhatikan. Apabila kebutuhan ini tidak terpenuhi selama jangka waktu tertentu akan dapat menurunkan daya tahan tubuh Balita dan dapat meningkatkan risiko terjadinya berbagai penyakit infeksi, disamping itu juga dapat menghambat tumbuh kembang Balita.

\section{Pengaruh Sirup Zink Terhadap Perubahan Berat Badan}

Berdasarkan Uji Statistik menggunakan Wilcoxon didapatkan $\mathrm{p}=0,034$ sehingga $\mathrm{p}<0,05$ yang menunjukkan $\mathrm{Ha}$ diterima artinya ada pengaruh pemberian sirup zink terhadap perubahan berat badan balita pada balita dengan KEP sedang.Hasil penelitian ini sesuai dengan teori yang menyatakan bahwa zink ini dapat membantu proses metabolisme dan membantu kerja enzim di dalam tubuh salah satunya akan meningkatkan fungsi enzim dalam tubuh. Jika fungsi enzim dalam tubuh berlangsung dengan baik, maka asupan makanan yang masuk ke 
dalam tubuh dapat mudah diserap dan berfungsi optimal dalam membantu proses pertumbuhan. (Almatsier, 2003).

Selain itu zink sebagai mineral mikro yang terdapat dalam jumlah sangat kecil di dalam tubuh memegang peranan penting dalam banyak fungsi tubuh.

Zink sebagai bagian dari enzim atau sebagai kofaktor pada kegiatan lebih dari dua ratus enzim, zink berperan dalam berbagai aspek metabolism, seperti reaksireaksi yang berkaitan dengan sintesis dan degradasi karbohidrat, protein, lipida dan asam nukleat. Sebagai bagian dari enzim peptidase karboksil yang terdapat di dalam cairan pancreas, zink berperan dalam pencernaan protein (Almatsier, 2003). Pemberian sirup zink pada penelitian ini dapat membantu proses metabolism dan membantu kerja enzim-enzim di dalam tubuh sehingga salah satunya akan meningkatkan fungsi enzim dalam tubuh sehingga dengan fungsi enzim dalam tubuh berlangsung dengan baik, maka asupan makanan yang masuk ke dalam tubuh dapat mudah diserap dan berfungsi optimal dalam membantu proses pertumbuhan. Hal ini tampak pada perubahan berat badan anak yang menderita gangguan gizi Beberapa faktor yang berpengaruh terhadap asupan makanan antara lain kebiasaan makanan, rasa suka dan tidak suka terhadap makanan tertentu akan terbawa sampai dewasa dan seringkali sulit diperbaiki, termasuk juga lingkungan keluarga, media massa, teman sebaya dan penyakit. Problema makan pada anak dapat berakibat buruk bagi tumbuh kembang anak. Sedikitnya makanan yang masuk ke dalam perut anak dapat menjadi indikasi bahwa anak mempunyai peluang besar untuk menderita kurang gizi

\section{KESIMPULAN}

1. Sebelum diberi perlakuan seluruhnya balita mempunyai status gizi berdasarkan BB/U dalam kategori rendah

2. Setelah pemberian sirup zink selama 2 bulan pada balita dengan KEP sedang, sebagian besar mengalami kenaikan berat badan.

3. Ada pengaruh pemberian sirup zink terhadap perubahan berat badan balita pada balita dengan KEP $\operatorname{sedang}($ pvalue 0,034$)$

Direkomendasikan untuk pemberian sirup zink diberikan selama 3 bulan dengan dosis 1,25 $\operatorname{mg}(1$ sendok teh) agar mendapatkan hasil yang optimal. Untuk peneliti selanjutnya, memasukkan variabel food recall untuk mengetahui penyebab KEP 


\section{UCAPAN TERIMA KASIH}

Dengan terselesainya penelitian ini, maka penulis mengucapkan terima kasih kepada:

1. Kemenristekdikti, BPPM/SPK/03/11/2018, 2018 atas dana hibah

2. Letkol Ckm Arief Effendie S, MPH, S.Kep.Ners, SH, MM selaku direktur Poltekkes RS dr Soepraoen

3. drg. Anitarini selaku Kepala UPTD Puskesmas Jabung yang telah memberikan ijin penelitian

4. Laila Qodariyah Amd. Gz yang telah membantu selama penelitian serta seluruh bidan desa wilayah kerja puskesmas jabung

\section{REFERENSI}

Agus Krisno B. (2001). Dasar-dasar Ilmu Gizi. Universitas Muhamadiyah Malang Press: Malang

Almatsier, S. (2008). Prinsip Dasar Ilmu Giz̨i. Jakarta : PT Gramedia Pustaka Umum

Basuni, A. (2003). Penilaian Status Gizi dengan Antropometri (BB dan TB), dalam Prosiding Konggres Nasional Persagi dan Temuan Ilmiah XII. Jakarta

Brown K.H and Sara E.W. (2000). Zinc and Human Health Result of Recent Trials and Implication for Program Intervention and Research. International Development Research Center: Ottawa, Canada.

Depkes. R.I., (2002). Pedoman Tata Laksanan KEP pada Anak di Puskesmas dan Rumah Tangga. Direktorat Bina Gizi Masyarakat. Jakarta.
Hidayat, A. (2009). Metode Penelitian Kebidanan dan Teknik Analisa Data. Jakarta: Salemba Medika

Midwifery. (2018). Data KEP. Diperoleh dari Http://www.sinarharapan.co.id

Mundiastuti L.(2002). Pengaruh Pemberian Suplemen Seng (Zn) terbadap Status Gizi Anak Usia 1-3 tabun di Kelurahan Bendul Merisi, Kecamatan Wonocolo dan di Kelurahan Jagir, Kecamatan Wonokromo, Kota Surabaya. Tesis. Program Pasca Sarjana UNAIR, Surabaya : 71-7.

Notoadmodjo, S. (2009). Metodologi Penelitian Kesehatan Edisi Revisi. Jakarta: Salemba Medika

Nursalam. (2009). Konsep dan Penerapan metodologi Penelitian Ilmu Keperawatan. Jakarta: Salemba Medika

Prawirohartono. (2012). Nutrien dan Angka Kecukupan Giri. Yogyakarta: Subbagian Gizi Anak, SMF Kesehatan Anak, RSUD Dr.Sardjito

Putri,RM., Maemunah,N., Rahayu,W (2016). Pemeriksaan Prtumbuhan dan Personal Higiene Anak Pra Sekolah di RA Pesantren Al Madaniyah. Jurnal Akeses Pengabdian Indonesia Vol 1 No 1: 55-64. https://jurnal.unitri.ac.id/ index.php/japi/article/view/459

Poedjiadi. (2010). Dasar-dasar Biokimia. Jakarta: Universitas Indonesia

Sugiyono. (2008). Statistika Untuk Peneliti. Bandung: Alfabeta

Suhardjo. (2008). Pemberian Makanan Pada Bayi dan Anak. Jogjakarta: Kanisius

Supariasa, IDN. (2009). Penilaian Status Giri. Jakarta: Penerbit Buku Kedokteran EGC

WHO.(1996). Zinc. Trace Elements in Human Nutrition and Health. Geneva : WHO, 72-104. 
Wuegard E, Kirchgessner M. (1980). Total True Efficiency of Zinc Utilization : Determination and Homeostatic Dependence Upon Zinc Supply Status in Young Rots. J Nutr $110: 469-80$. 